\title{
FAKTOR YANG MEMPENGARUHI MINAT BELI PRODUK MAKANAN DAN MINUMAN USAHA KECIL MENENGAH KABUPATEN TANGERANG
}

\author{
Yohana F. Cahya Palupi Meilani dan Sahat Simanjuntak \\ Deputy of Head Management Department, Business School Universitas Pelita Harapan \\ Karawaci-Tangerang, Indonesia \\ Email: yohana_cahya@uph.edu; sahat_simanjuntak@uph.edu
}

\begin{abstract}
Abstrak
Penelitian ini bertujuan untuk melihat pengaruh kualitas produk, layanan yang dirasakan dan harga terhadap minat beli produk-produk UKM Kabupaten Tangerang. Jenis penelitian adalah kuantitatif. Obyek penelitian adalah UKM Kabupaten Tangerang. Subyek penelitian adalah konsumen produk UKM. Data dikumpulkan melalui personally-administered questionnaires menggunakan convenience sampling. Analisis menggunakan regresi berganda. Secara simultan, kualitas produk, layanan yang dirasakan dan harga berpengaruh terhadap minat beli. Secara parsial, kualitas produk dan harga berpengaruh pada minat beli. Sementara layanan yang dirasakan tidak memiliki pengaruh pada minat beli.
\end{abstract}

Kata Kunci: Kualitas Produk, Layanan yang Dirasakan, Harga, Minat Beli, UKM Tangerang.

\begin{abstract}
The purpose of this research was to see the influence of product quality, perceived service, and price to buying interest to the SMEs products in Tangerang. The research type was quantitative. The research object and subject were SMEs in Tangerang and consumers. The data was collected by personally administered questionnaires that utilized convenience sampling method. The analysis method used multiple regression. Product quality, perceived service and price affectted to buying interest simultaneously. Product quality and price affected to buying interest partially; while perceived service had no impact to buying interest.
\end{abstract}

Keywords: Product Quality, Perceived Service, Price, Buying Interest, SMEs of Tangerang

\section{PENDAHULUAN}

Organisasi bisnis termasuk Usaha kecil Menengah (UKM)yang ingin berkembang harus dapat memberikan barang atau jasa yang bernilai lebih tinggi kepada pelanggan. Sementara itu di Indonesia, perekonomian juga disokong oleh keberadaan UKM yang memberikan kontribusi besar terhadap penyerapan tenaga kerja, Produk Domestik Bruto (PDB) dan ekspor. Ciri-ciri usaha mikro menurut Dinas Koperasi dan UKM adalah Jenis barang/ komoditas usahanya tidak selalu tetap, sewaktu-waktu dapat berganti; tempat usahanya tidak selalu sama, dapat berpindah-pindah; terkadang belum melakukan manajemen keuangan, sumber daya manusia masih ada yang belum memiliki jiwa wirausaha yang memadai; biasanya belum akses kepada perbankan, namun sebagian dari mereka sudah akses ke lembaga keuangan bukan bank; terkadang belum mempunyai izin usaha.
UKM yang ada masih mengalami hambatan dalam pengembangan usaha. Kotler (2005) mengemukakan penerapan konsep pemasaran modern berorientasi pasar atau pelanggan merupakan hal penting bagi keberhasilan pemasaran. Produk-produk UKM Kabupaten Tangerang sebagai produk lokal, seharusnya juga memiliki keunggulan kompetitif. Menteri Perdagangan menyampaikan target penyerapan produk UKM pada tahun 2010 diharapkan menjadi $30 \%$ selama lima tahun ke depan. Masalah yang masih menghambat masuknya produk UKM di gerai ritel modern, di antaranya masalah standar, continuity supply, packaging, dan desain. UKM dapat berkembang lebih maju, salah satu cara yang dapat dilakukan adalah dengan meningkatkan minat beli konsumen.

Hasil studi eksplorasi pertama terhadap 100 orang responden di lingkungan Universitas Pelita Harapan (UPH), Karawaci Tangerang tentang minat beli terhadap produk UKM Tangerang berdasarkan 
kategori produk-produk UKM Kabupaten Tangerang: produk makanan, minuman $(62 \%)$; produk busana: kain batik, kain/bahan pakaian, pakaian jadi, kerudung, topi, peci (13\%); produk pelengkap busana: dompet, tas, sepatu, sandal, aksesoris dan sejenisnya (15\%); produk furniture: kitchen set, almari, kursi, meja, dan sejenisnya (10\%); produk hiasan rumah: kerajinan kayu, anyaman rotan, gerabah, lukisan (10\%); produk alat olahraga: bola sepak (0\%). Hasil menunjukkan 62 responden $(62 \%)$ menyatakan melakukan pembelian pada kategori produk makanan, minuman.

Studi eksplorasi kedua terhadap 30 responden di UPH Karawaci, yang pernah melakukan pembelian produk UKM dalam jenis makanan dan minuman, $37 \%$ menyatakan melakukan pembelian dari kios/ toko dekat rumah. Sebanyak 40\% melakukan pembelian di daerah Karawaci. Responden sebanyak 76\% menyatakan produk makanan, minuman UKM Kabupaten Tangerang sukar diidentifikasi/dikenali sehingga sulit bagi yang ingin melakukan pembelian. Padahal produk makanan, minuman UKM Kabupaten Tangerang sebagai contoh sate bandeng, keripik singkong, keripik jamur, kerupuk ikan, batagor, tahu bulat mapuci, camilan jipang, es buah, susu kedelai, minuman jahe merah diharapkan untuk tetap bertahan dan bahkan dapat diekspor. Sesuai pernyataan 57\% responden setuju apabila produk makanan minuman UKM Kabupaten Tangerang diekspor. Beberapa penelitian juga menunjukkan bahwa kualitas produk, layanan, dan harga merupakan faktor yang penting dalam mempengaruhi minat beli konsumen (Albari \& Liriswati, 2004; Sheila \& Rahma, 2007; Dewa 2009).

Berdasarkan latar belakang di atas dapat dirumuskan permasalahan sebagai berikut, yaitu: Apakah terdapat pengaruh kualitas produk, layanan yang dirasakan, harga terhadap minat beli produk makanan dan minuman UKM Kabupaten Tangerang? Penelitian ini bertujuan untuk melihat faktor yang mempengaruhi minat beli produk makanan dan minuman UKM Kabupaten Tangerang, meliputi kualitas produk, layanan yang dirasakan dan harga.

\section{LANDASAN TEORI DAN HIPOTESIS}

Produk tidak bersifat jangka panjang, karena dengan teknologi yang semakin berkembang membuat produk harus lebih berkreasi menyamakan dengan perkembangan. Perusahaan harus mengetahui keinginan pasar seperti apa dan lebih baiknya perusahaan dalam menciptakan produk baru yang kreatif dan membuat konsumen yang tadinya tidak membutuhkan menjadi sangat membutuhkan produk tersebut (Tjiptono, 2009). Semakin tinggi kualitas produk semakin tinggi minat beli. Hipotesis pertama: $\mathrm{H}_{1}$ : Kualitas produk berpengaruh pada minat beli
Jasa adalah tiap kegiatan atau manfaat yang dapat ditawarkan satu pihak ke pihak yang lainnya dalam jaringan jasa yang pada dasarnya tidak berwujud dan tidak mengakibatkan kepemilikan apapun (Keller \& Kevin, 1987, p. 196). Semakin baik layanan yang dirasakan semakin tinggi minat beli. Hipotesis kedua:

$\mathrm{H}_{2}$ : Layanan yang dirasakan berpengaruh pada minat beli

Menurut Kotler (2005, p. 518) bahwa harga adalah nilai yang ada di sekeliling kita. Harga juga didefinisikan sebagai jumlah uang yang dibutuhkan guna mendapatkan sejumlah kombinasi dari barang beserta pelayanannya (Swastha, 1998, p. 241). Dari definisi di atas tentang harga, dapat disimpulkan bahwa harga adalah nilai suatu barang atau jasa yang diukur dengan sejumlah uang dikeluarkan oleh pembeli agar mendapatkan sejumlah kombinasi dari barang/jasa beserta pelayanannya. Harga merupakan pengorbanan ekonomis yang dilakukan pelanggan untuk memperoleh produk atau jasa. Hipotesis ketiga: $\mathrm{H}_{3}$ : Harga berpengaruh pada minat beli

Model penelitian yang dibangun berdasarkan hipotesis dapat dilihat pada Gambar 1 bahwa terdapat faktor yang mempengaruhi minat beli produk makanan dan minuman UKM Kabupaten Tangerang, meliputi kualitas produk, kualitas layanan dan harga. Model penelitian ini dibangun berdasarkan model penelitian Sheila \& Rahma (2007).

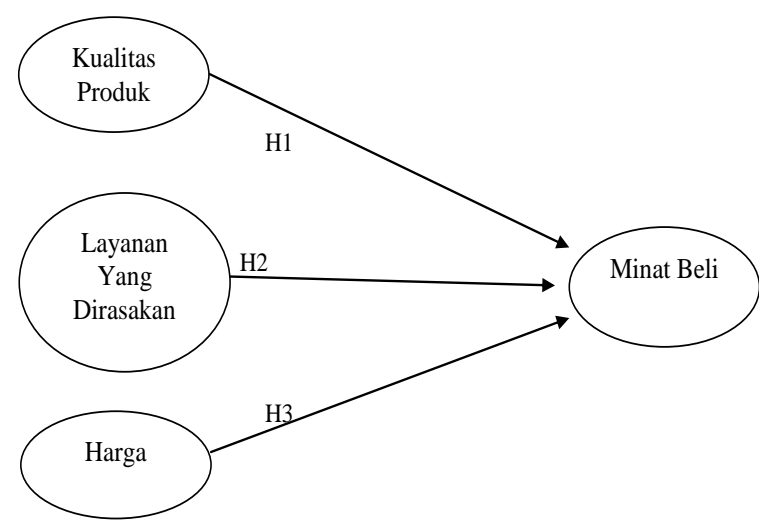

Sumber: Adopsi dari Sheila \& Rahma, 2007 dan Budiyono \& Bernard, 2004

\section{Gambar 1. Model Penelitian}

\section{METODE PENELITIAN}

Obyek penelitian adalah UKM Kabupaten Tangerang. Pemilihan UKM Kabupaten Tangerang karena sejak 2010 telah menghasilkan beberapa kategorial produk utama, meliputi: produk makanan, minuman, camilan; produk busana: kain batik, kain/ 
bahan pakaian, pakaian jadi, kerudung, topi, peci; produk pelengkap busana: dompet, tas, sepatu, sandal, aksesoris dan sejenisnya; produk furniture: kitchen set, almari, kursi, meja, dan sejenisnya; produk hiasan rumah: kerajinan kayu, anyaman rotan dan bambu, gerabah, lukisan; produk alat olahraga: bola sepak. Selain itu Kabupaten Tangerang telah menyandang predikat sebagai sentra industri terutama untuk komoditas tekstil, pakaian jadi, kulit dengan pendapatan dari industri tersebut sebesar 2,6 triliun rupiah. Pemilihan produk makanan dan minuman UKM Kabupaten Tangerang berdasarkan studi eksplorasi pertama terhadap 100 orang pembeli produk UKM Tangerang diperoleh $62 \%$ responden melakukan pembelian untuk kategorial produk makanan dan minuman.

Subyek penelitian adalah konsumen produkproduk makanan dan minuman UKM Kabupaten Tangerang di lingkungan UPH yang pernah melakukan transaksi pembelian minimal satu kali dalam kurun waktu satu tahun, dengan usia di atas 18 tahun. Pemilihan usia tersebut berdasarkan KUHP perdata pasal 421 dan 426 tentang pendewasaan penuh syaratnya telah berumur 18 tahun penuh. Responden penelitian ini adalah yang memenuhi syarat dan ketentuan karakterisitik sesuai tujuan penelitian. Responden dipilih yaitu mengetahui asal produk yang pernah dibeli berasal dari UKM Tangerang.

Jenis penelitian ini deskriptif kuantitatif. Penelitian ini merupakan replikasi dari penelitian Sheila \& Rahma (2007) dan Budiyono \& Bernard (2004) yang artinya mengikuti model yang digunakan dalam penelitian sebelumnya.

Data yang dipakai adalah data cross-sectional, dilakukan dengan kuesioner dan desain sampel nonprobabilitas. Oleh karena keterbatasan informasi dalam mencari populasi responden pembeli produk makanan dan minuman UKM Kabupaten Tangerang yang luas maka teknik convenience sampling diterapkan dalam penelitian ini.

Jumlah sampel yang akan digunakan adalah 200 responden. Sekaran (2010, p. 296) menyatakan ukuran sampel lebih dari 30 dan kurang dari 50 merupakan ukuran yang sesuai untuk kebanyakan penelitian. Untuk penelitian menggunakan analisis multiple regression sebaiknya jumlah sampel minimal sepuluh kali dari jumlah variabel yang digunakan. Jumlah variabel yang dipakai dalam penelitian ini adalah empat (kualitas produk, layanan yang dirasakan, harga, minat beli), berarti sampel minimum adalah empat puluh $(4 \times 10=40)$. Penelitian ini yang sudah memenuhi persyaratan minimum sampel, karena jumlah sampel yang dipakai lebih dari empat puluh.

Variabel yang digunakan dalam penelitian ini meliputi variabel bebas dan variabel terikat. Variabel bebas yang mempengaruhi varibel terikat yaitu kualitas produk, layanan yang dirasakan dan harga. Variabel terikat sebagai ketertarikan peneliti yaitu minat beli.

Kuesioner yang digunakan diadopsi dari Budiyono \& Bernard (2004), Dewa (2009) dan Sheila \& Rahma (2007) dengan modifikasi, disesuaikan tujuan penelitian. Skala dalam kuesioner yaitu skala likert lima poin untuk menunjukkan seberapa kuat perasaan responden setuju atau tidak setuju dengan butir pernyataan. Hasil dari jawaban dalam bentuk angka, 1 = sanga $\mathrm{t}$ tidak setuju, $2=$ tidak setuju, $3=$ netral, $4=$ setuju, 5 = sangat setuju. Skor netral digunakan untuk mengakomodir kebutuhan responden yang memiliki sikap netral. Uraian definisi konseptual dan operasional dapat dilihat pada Tabel 1 yang menunjukkan bahwa tiap variabel dalam penelitian meliputi kualitas produk, layanan yang dirasakan, harga dan minat beli diberikan indikator dipakai pada kuesioner. Item-item kuesioner akan digolongkan berdasarkan measurement konstruk yang sama untuk memperoleh nilai validitas diskriminan yang baik.

Analisis data menggunakan regresi berganda dengan alat bantu program SPSS 16. Uji statistik dilakukan dengan melihat koefisien determinasi $\left(\mathrm{R}^{2}\right)$ dan menilai berdasarkan nilai statistik pada uji $\mathrm{F}$ dan uji t.

\section{HASIL PENELITIAN DAN PEMBAHASAN}

Pengelompokan responden yang menjadi sampel dijabarkan berdasarkan lima kategori, yaitu gender, usia, pekerjaan, pengeluaran perbulan. Deskripsi masing-masing kelompok responden sekiranya dapat membantu memahami hasil analisis yang diperoleh. Responden pria sebanyak 59,5\% > wanita sebanyak 40,5\% dikarenakan pria lebih sering melakukan pembelian produk makanan dan minuman di lokasi tempat belajar/ kerja daripada wanita. Usia 18-27 tahun sebanyak 76,7 \% yaitu usia dewasa awal hingga dewasa sehingga dapat mengambil keputusan sendiri dalam pembelian. Pekerjaan mahasiswa sebanyak 60\% karena penelitian dilakukan di kampus UPH. Pengeluaran sebulan mayoritas pada satu sampai tiga juta rupiah sebanyak $41 \%$ sesuai kemampuan responden mayoritas yaitu mahasiswa. 
Tabel 1. Definisi Konseptual dan Definisi Operasional

\begin{tabular}{|c|c|c|c|c|c|}
\hline Variabel & Konseptual & & Indikator & Skala & Sumber \\
\hline $\begin{array}{l}\text { Kualitas } \\
\text { produk }\end{array}$ & $\begin{array}{l}\text { Kualitas dapat dinyatakan sebagai } \\
\text { harapan dan persepsi konsumen } \\
\text { yang sama baiknya dengan } \\
\text { kualitasyang sesungguhnya } \\
\text { (Budiyono \& Bernard, 2004) }\end{array}$ & 2. & $\begin{array}{l}\text { Produk makanan/minuman UKM } \\
\text { Tangerang aman dikonsumsi } \\
\text { Produk makanan/minuman UKM } \\
\text { Tangerang memiliki kualitas yang } \\
\text { baik. } \\
\text { Produk makanan/minuman UKM } \\
\text { Tangerang nikmat dikonsumsi }\end{array}$ & $\begin{array}{l}\text { Likert scale (1-5) } \\
\text { Likert scale }(1-5)\end{array}$ & $\begin{array}{l}\text { Budiyono \& } \\
\text { Bernard } \\
(2004)\end{array}$ \\
\hline $\begin{array}{l}\text { Layanan } \\
\text { Yang } \\
\text { Dirasakan }\end{array}$ & $\begin{array}{l}\text { Fungsi dari } \\
\text { apa yang diterima secara } \\
\text { aktual oleh pelanggan } \\
\text { (kualitas teknis), dan bagaimana } \\
\text { cara layanan } \\
\text { Tersebut disampaikan } \\
\text { (kualitas fungsional). } \\
\text { (Sheila \& Rahma, 2007) }\end{array}$ & & $\begin{array}{l}\text { Pelayanan di gerai produk makanan/ } \\
\text { minuman UKM Tangerang ramah } \\
\text { Gerai penjualan produk makanan/ } \\
\text { minuman UKM Tangerang nyaman. } \\
\text { Fasilitas di gerai penjualan } \\
\text { makanan/minuman UKM Tangerang } \\
\text { baik }\end{array}$ & $\begin{array}{l}\text { Likert scale }(1-5) \\
\text { Likert scale }(1-5) \\
\text { Likert scale }(1-5)\end{array}$ & $\begin{array}{l}\text { Sheila \& } \\
\text { Rahma } \\
(2007)\end{array}$ \\
\hline
\end{tabular}

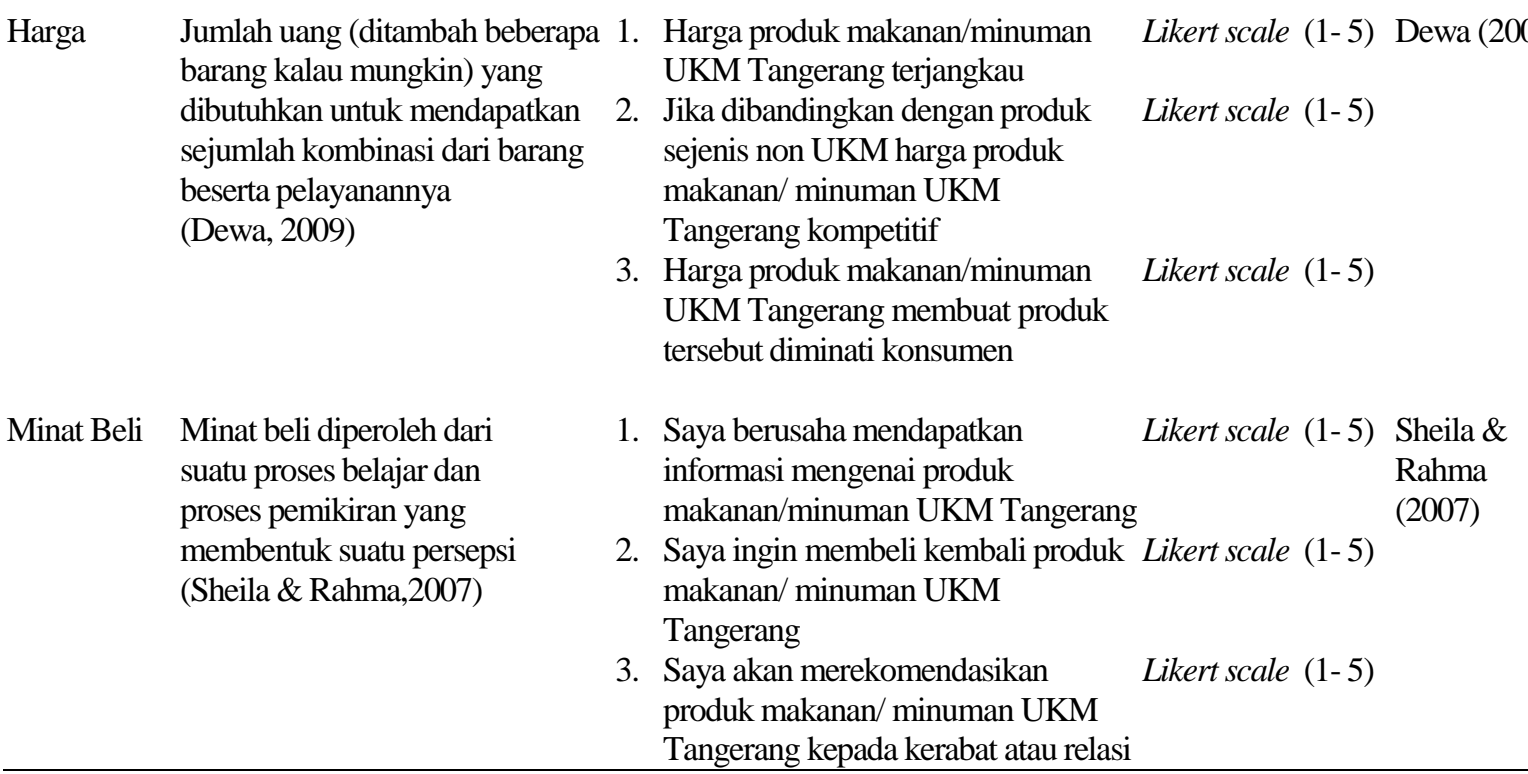

Hasil pengujian validitas pretes dan aktual menunjukkan standardized loading estimate yang diperoleh adalah di atas nilai 0,50. Validitas pretes nilai standardized loading estimate yang diperoleh 0,536 sampai dengan 0,886 . Validitas aktual nilai standardized loading estimate yang diperoleh 0,661 sampai 0,884.Jadi dapat dikatakan semua indikator valid, maka semua indikator di atas dapat dikatakan telah terpenuhi persyaratan validitas konstruk.

Hasil pengujian reliabilitas pretes dan reliabilitas aktual menunjukkan bahwa nilai Cronbach alpha faktor kualitas produk, layanan yang dirasakan, harga dan minat beli lebih besar dari 0,7 yang berarti data yang terkumpul pada tahap pra analisis sudah dapat diandalkan dalam mengumpulkan informasi yang dibutuhkan. Kisaran nilai Cronbach alpha sesuai uji reliablitas pretes adalah sebesar hingga 0,708 sampai
0,805 , sedang pada uji reliabilitas aktual yaitu 0,821 sampai 0,847 sehingga dapat disimpulkan bahwa data yang diperoleh memiliki tingkat keandalan yang tinggi atau baik karena nilai cronbach alpha adalah > 0,60 . Nilai corrected item total correlation $>0,2352$, baik pada pretes maupun aktual maka hasil pengukuran dapat dikatakan reliabel.

Statistik deskripstif ditampilkan pada Tabel 2 dengan melihat nilai rata-rata, standar deviasi dan jarak sesuai.

Pada Tabel 2 statistik deskriptif dapat dilihat bahwa indikator kualitas produk 1 yang diwakili oleh pertanyaan "Produk makanan/minuman UKM Tangerang aman dikonsumsi" memperoleh rata-rata 3,76 dengan standart deviasi 0,91 . Hasil tersebut dapat dikatakan bahwa kebanyakan responden menjawab "netral" menuju " setuju". 
Tabel 2. Statistik Deskriptif

\begin{tabular}{|c|c|c|c|c|c|}
\hline & $\mathbf{N}$ & $\begin{array}{l}\text { Mini- } \\
\text { mum }\end{array}$ & $\begin{array}{l}\text { Maxi } \\
\text { mum }\end{array}$ & Mean & $\begin{array}{c}\text { Std. } \\
\text { Devia- } \\
\text { tion }\end{array}$ \\
\hline KUALITASPRODUK 1 & 200 & 1.00 & 5.00 & 3.7650 & .91321 \\
\hline KUALITASPRODUK 2 & 200 & 1.00 & 5.00 & 3.7300 & .92269 \\
\hline KUALITASPRODUK 3 & 200 & 2.00 & 5.00 & 3.8850 & .75806 \\
\hline LAYANAN 1 & 200 & 1.00 & 5.00 & 3.0300 & .76553 \\
\hline LAYANAN 1 & 200 & 1.00 & 5.00 & 2.6800 & .75528 \\
\hline LAYANAN 3 & 200 & 1.00 & 5.00 & 3.0450 & .84412 \\
\hline HARGA 1 & 200 & 1.00 & 5.00 & 4.0500 & .72118 \\
\hline HARGA 2 & 200 & 1.00 & 5.00 & 4.0250 & .64534 \\
\hline HARGA 3 & 200 & 2.00 & 5.00 & 3.9600 & .65617 \\
\hline MINATBEI & 200 & 1.00 & 5.00 & 3.5100 & .90776 \\
\hline MINATBELI 2 & 200 & 2.00 & 5.00 & 3.7450 & .70174 \\
\hline MINATBELI 3 & 200 & 2.00 & 5.00 & 3.6650 & .77833 \\
\hline Valid N (listwise) & 200 & & & & \\
\hline
\end{tabular}

Dapat dikatakan pada variabel kualitas produk rata-rata responden menjawab hampir mendekati kesetujuan yang artinya menurut responden kualitas produk makanan dan minuman UKM Tangerang aman, berkualitas baik dan nikmat. Nilai rata-rata yang paling baik di antara variabel terikat adalah variabel harga (rata-rata 3.96 sampai 4.05) yang menunjukkan responden setuju bahwa harga produk makanan minuman UKM Tangerang terjangkau, kompetitif, membuat diminati. Variabel kualitas layanan memiliki rata-rata 2,6 sampai 3,0 sehingga menunjukkan tingkat kesetujuan responden atas kualitas layanan produk makanan minuman UKM Tangerang adalah 'tidak setuju menuju netral'.

\section{Uji Autokorelasi}

Untuk mengetahui apakah penelitian ini terjadi autokorelasi atau tidak, maka proses yang digunakan adalah metode Durbin Watson (D-W). Berdasarkan Tabel 3 nilai D-W yang dihasilkan adalah 2,096 atau di antara -2 sampai +2 dari nilai ambang, maka dapat disimpulkan bahwa tidak terjadi autokorelasi di antara variabel bebas terhadap variabel terkait (Ghozali, 2009 , p. 100).

Tabel 3. Uji Autokorelasi Durbin-Watson

\begin{tabular}{cccccc}
\hline Model & $\mathbf{R}$ & $\begin{array}{c}\boldsymbol{R} \\
\text { Square }\end{array}$ & $\begin{array}{c}\text { Adjusted } \\
\text { R Square }\end{array}$ & $\begin{array}{c}\text { Std. Error Durbin- } \\
\text { of the } \\
\text { Estimate }\end{array}$ & $\begin{array}{c}\text { Watson } \\
\text { S }\end{array}$ \\
\hline 1 & $.605^{\mathrm{a}}$ & .366 & .356 & .56819 & 2.096 \\
\hline
\end{tabular}

\section{Uji Multikolenearitas}

Tabel 4 memperlihatkan uji multikolenearitas terhadap masing-masing variabel independen dengan variabel dependen, diperoleh hasil VIF tiga variabel independen di atas angka 10. Dan memiliki angka toleransikurang daril pada variabel kualitas produk. Maka kesimpulannya adalah model regresi tersebut tidak terdapat multikolenearitas.

Tabel 4. Uji Multikolenearitas

\begin{tabular}{lcc}
\hline \multirow{2}{*}{ Model } & \multicolumn{2}{c}{ Statistik Kolenearitas } \\
\cline { 2 - 3 } & Toleransi & VIF \\
\hline KUALITAS PRODUK & .803 & 1.853 \\
LAYANAN & .569 & 1.758 \\
HARGA & .549 & 1.834 \\
\hline
\end{tabular}

\section{Uji Normalitas}

Pengujian normalitas pada Gambar 2 pada penelitian ini menggunakan grafik, dengan melihat penyebaran yang terjadi apakah menyebar di sekitar garis diagonal dan mengikuti garisdiagonal atau tidak. Hasil yang didapatkan untuk penelitian ini adalah berdistribusi normal, karena menyebar di sekitar garis diagonal dan mengikuti garis diagonal.

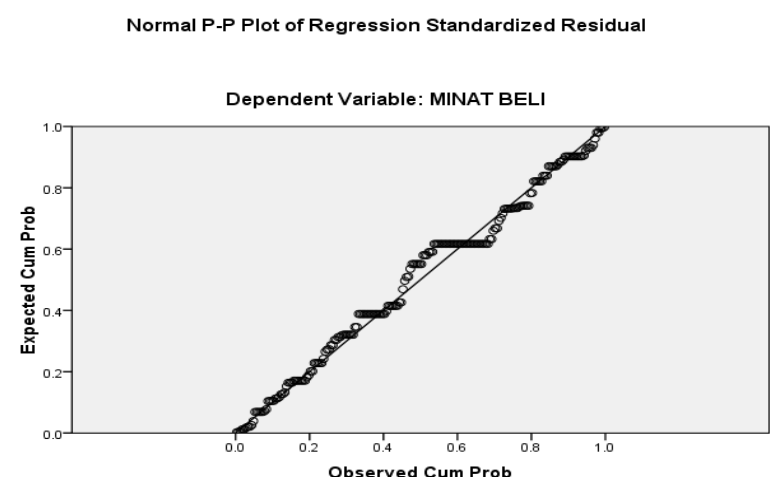

Gambar 2. Uji Normalitas

\section{Uji Heteroskedastisitas}

Heteroskedastisitas menunjukkan bahwa varians dari setiap error bersifat heterogen yang berarti melanggar asumsi klasik yang mensyaratkan bahwa varians dari error harus bersifat homogen. Masalah heteroskedastisitas umum terjadi dalam data cross section yaitu data yang diambil pada satu waktu saja, tetapi dengan responden yang besar, misalnya jika melakukan survai. 


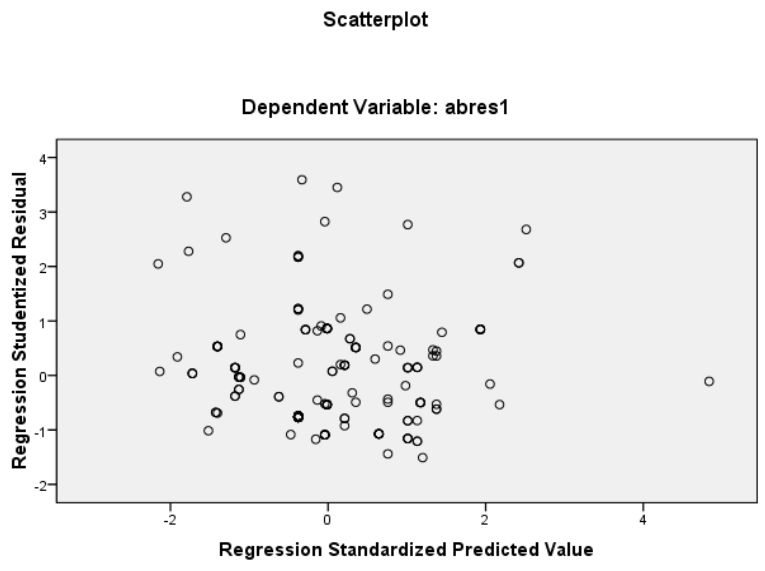

Gambar 3. Uji Heteroskedastisitas

Uji heteroskedastisitas dapat dilihat berdasarkan hasil graphical test of equal variance pada Gambar 3. Dari Gambar 3 tersebut terlihat bahwa data dikatakan tidak terjadi heteroskedasitas karena menyebar secara acak serta tersebar baik di atas maupun di bawah angka 0 pada sumbu $Y$.

\section{Analisis Multiple Regression}

Analisis regresi berganda sesuai Tabel 5 bahwa $\mathrm{R}$ pada model sebesar 0,605 dan ditunjukkan bahwa hasil koefisien determinasi (adjusted $\mathrm{R}^{2}$ ) adalah sebesar 0,356.

Tabel 5. Regresi Berganda

\begin{tabular}{ccccc}
\hline Model & $\mathbf{R}$ & $\boldsymbol{R}$ Square & $\begin{array}{c}\text { Adjusted } \boldsymbol{R} \\
\text { Square }\end{array}$ & $\begin{array}{c}\text { Std. Error of the } \\
\text { Estimate }\end{array}$ \\
\hline 1 & $.605^{\mathrm{a}}$ & .366 & .356 & .56819 \\
\hline
\end{tabular}

Hasil menunjukkan bahwa 35,6\% variabel minat beli dijelaskan secara bersama-sama oleh 3 variabel independen yaitu kualitas produk, kualitas layanan, harga. Sisanya $64,4 \%$ disebabkan oleh faktor lain diluar penelitian seperti contohnya merek, bauran pemasaran. Hal ini terjadi dikarenakan variabel untuk menjelaskan variabel minat beli masih sedikit, hanya 3 variabel. Standart error of estimate (SEE) adalah 0,568 tergolong tinggi, padahal nilai SEE makin kecil membuat model regresi makin tepat memprediksi variabel dependen minat beli.

\section{Uji Statistik F}

Uji F atau uji ANOVA pada Tabel 6 menunjukkan bahwa nilai $\mathrm{F}$ hitung sebesar 37,69 lebih besar dari $\mathrm{F}$ tabel $(2,65)$. Hasil nilai signifikansi lebih kecil dari 0,05 maka menunjukkan model layak dan signifikan (Ghozali, 2009, p. 88).
Tabel 6. Uji Statistik F

\begin{tabular}{lccccc}
\hline \multicolumn{1}{c}{ Model } & $\begin{array}{c}\text { Sum of } \\
\text { Squares }\end{array}$ & $\boldsymbol{d f}$ & $\begin{array}{c}\text { Mean } \\
\text { Square }\end{array}$ & $\boldsymbol{F}$ & Sig. \\
\hline Regression & 36.509 & 3 & 12.170 & 37.695 & $.000^{\mathrm{a}}$ \\
Residual & 63.277 & 196 & .323 & & \\
Total & 99.785 & 199 & & & \\
\hline
\end{tabular}

\section{Uji Statistik t}

Uji statistik t dapat dilihat sesuai Tabel 7 Kualitas produk nilai t hitung $(1,75)>t$ tabel $(1,653)$, demikian juga untuk harga $t$ hitung $(1,777)>t$ tabel $(1,653)$. Sedang nilai $t$ hitung pada varibael layanan yang dirasakan $(0,361)<\mathrm{t}$ tabel $(1,653)$.

\section{Tabel 7. Uji Statistik t}

\begin{tabular}{lcccccc}
\hline Model & \multicolumn{2}{c}{$\begin{array}{c}\text { Unstandardized } \\
\text { Coefficients }\end{array}$} & $\begin{array}{c}\text { Standardized } \\
\text { Coefficients }\end{array}$ & t & Sig. \\
\cline { 2 - 4 } & B & $\begin{array}{c}\text { Std. } \\
\text { Error }\end{array}$ & Beta & & \\
\hline (Constant) & .994 & .266 & & 3.731 & .000 \\
KUALITAS & .236 & .188 & .252 & 1.750 & .021 \\
PRODUK & & & & & & \\
LAYANAN & .122 & .339 & .111 & .361 & .718 \\
HARGA & .351 & .198 & .292 & 1.777 & .037 \\
\hline
\end{tabular}

Dalam menginterpretasikan koefisien regresi dapat dilihat pada Tabel 7 nilai t tidak memenuhi signifikansi adalah pada variabel layanan yang dirasakan. Jadi model regresinya:

$$
\mathrm{Y}=0,994+0,236 \text { Kualitas produk }+0,351 \text { harga }
$$

Hasil tersebut dapat dijelaskan bahwa berdasarkan unstandardized coefficient (B) jika nilai keseluruhan variabel adalah konstan, maka nilai minat beli adalah 0,994. Koefisien regresi pada variabel kualitas produk sebesar 0,236 ; variabel layanan yang dirasakan 0,122; variabel harga 0,351 akan memberikan penambahan nilai kepada minat beli. Artinya adalah apabila kualitas produk yang selalu baik terus ditingkatkan maka minat beli konsumen akan meningkat. Layanan yang baik dan terus dijaga akan meningkatkan minat beli. Harga bersaing akan meningkatkan minat beli.

\section{Interpretasi Manajerial}

Penelitian ini menggunakan metode multiple regression dalam pengujian hipotesis dan hasil pengujian tersebut dapat dilihat pada Tabel 7. Hasil pengujian hipotesis menjelaskan bahwa variabel memiliki pengaruh yang signifikan adalah kualitas produk dan harga, dikarenakan hasil signifikannya < 
0,05 dan melihat pada nilai $\mathrm{t}$ tabel $(1,653)$. Dapat dikatakan bahwa:

$\mathrm{H}_{1}$ : Terdapat pengaruh kualitas produk pada minat beli diterima.

$\mathrm{H}_{2}$ : Terdapat pengaruh layanan yang dirasakan pada minat beli ditolak.

$\mathrm{H}_{3}$ : Terdapat pengaruh harga pada minat beli diterima.

\section{Interpretasi Kualitas Produk terhadap Minat Beli}

Pengujian Hipotesis pertama menjelaskan terjadi pengaruh yang signifikan kualitas produk terhadap minat beli. Variabel kualitas produk memiliki pengaruh dan hipotesis kualitas produk diterima, karena hasil uji t variabel kualitas produk sebesar 0,252 pada signifikansi 0,021. Produk adalah strategi yang penting untuk dapat tetap kompetitif dalam menghadapi segala hal dari peningkatan maupun penurunan permintaan yang sering terjadi di dalam bisnis (Tjiptono, 2009, p. 25-26). Memberikan kualitas produk yang terbaik adalah suatu keharusan bagi setiap pelaku usaha termasuk produk makanan minuman UKM Tangerang, semakin baik kualitas produk yang diberikan maka konsumen akan semakin berminat untuk melakukan pembelian. Kualitas produk perusahaan memberikan pelayanan yang berwujud dan berharap produk tersebut akan menjadi kebutuhan masyarakat (Tjiptono, 2009, p. 34,47).

Pada indikator kualitas produk sesuai Tabel 2 statistik deskriptif, indikator yang paling diperhatikan oleh konsumen produk makanan dan minuman UKM Tangerang adalah indikator KP3 dengan mean 3,885 (mendekati setuju). Pertanyaan KP3 adalah "Produk makanan/minuman UKM Tangerang nikmat dikonsumsi”. Indikator KP3 ini memberikan gambaran bahwa produk makanan dan minuman telah memiliki rasa yang nikmat menurut responden. Nikmat menurut Kamus Besar Bahasa Indonesia dapat didefinisikan sebagai enak; lezat. Rasa nikmat merupakan persepsi atas kualitas sebuah produk

\section{Interpretasi Layanan yang Dirasakan terhadap Minat Beli}

Layanan yang dirasakan mempengaruhi minat beli seorang konsumen dilihat berdasarkan semakin bagus layanan yang diberikan akan semakin tinggi minat beli. Konsumen cenderung mengingat pengalaman yang mereka dapat, maka penjual seharusnya memberikan layanan yang baik kepada konsumen, agar menimbulkan minat beli. Semakin baik layanan yang dirasakan semakin tinggi minat beli. Pengujian Hipotesis kedua menjelaskan tidak terjadi pengaruh yang signifikan layanan yang dirasakan terhadap minat beli. Sheila \& Rahma (2007) mengemukakan bahwa layanan yang baik akan mendorong minat beli konsumen. Pada penelitian ini variabel layanan yang dirasakan justru tidak berpengaruh terhadap minat beli dan hipotesis layanan yang dirasakan terhadap minat beli ditolak, karena hasil uji-t kualitas layanan sebesar 0,111 pada signifikansi 0,718. Sesuai stastistik deskriptif Tabel 2 indikator kualitas layanan, rataratanya (mean) 2,68-3,045 (mendekati netral=3). Pertanyaan KL1, KL2, KL3: Pelayanan di gerai produk makanan/ minuman UKM Tangerang ramah, Gerai penjualan produk makanan/minuman UKM Tangerang nyaman, Fasilitas di gerai penjualan makanan/minuman UKM Tangerang baik.

Hipotesis kedua ditolak dikarenakan layanan yang dirasakan adalah pada saat konsumen dan produsen berinteraksi secara langsung, meskipun layanan yang dirasakan belum maksimal tetapi pembeli kurang mempedulikan hal tersebut. Dalam hal ini pembeli makanan/minuman produk UKM Tangerang lebih memperhatikan kualitas produk yaitu aman dikonsumsi, kualitas yang baik, nikmat dengan nilai rata-rata statistik deskriptif mendekati nilai 4 (setuju). Selain itu faktor harga menjadi pertimbangan karena rata-rata nilai kesetujuan responden (Tabel 2) atas harga yang terjangkau, kompetitif di atas nilai empat.

\section{Interpretasi Harga terhadap Minat Beli}

Pengujian Hipotesis ketiga menjelaskan terjadi pengaruh yang signifikan harga terhadap minat beli. Variabel harga memiliki pengaruh dan hipotesis ketiga didukung, karena hasil uji $\mathrm{t}$ variabel kualitas produk sebesar 0,292 pada signifikansi 0,037. Harga memegang peran yang penting dalam pemasaran produk makanan dan minuman UKM Tangerang. Harga merupakan salah satu penentu keberhasilan suatu perusahaan karena harga menentukan seberapa besar keuntungan yang akan diperoleh perusahaan dari penjualan produknya baik berupa barang maupun jasa. Penetapan harga yang sesuai harapan konsumen akan mempengaruhi minat beli. Dalam hal ini responden setuju bahwa harga produk makanan minuman UKM Tangerang terjangkau, kompetitif, membuat diminati terlihat dari rata-rata jawaban responden pada Tabel 2 statistik deskriptif adalah mendekati kesetujuan yaitu 3,96-4,0.

\section{SIMPULAN DAN SARAN}

Kualitas produk memiliki pengaruh terhadap minat beli. Dari hasil signifikansi $(0,021)$ dan nilai koefisien regresi $(0,252)$. Hipotesis pertama dalam 
penelitian ini diterima. Kualitas produk makanan/ minuman yang ditawarkan pelaku UKM di Tangerang telah menimbulkan minat beli konsumen, karena konsumen dapat merasakan bahwa kelezatan, kenikmatan dari produk makanan/minuman yang di beli telah memenuhi apa yang konsumen harapkan.

Kualitas layanan tidak memiliki pengaruh terhadap minat beli. Dari hasil signifikansi $(0,718)$ dan nilai koefisien regresi $(0,11)$ kualitas layanan tidak mempengaruhi minat beli konsumen. Hipotesis kedua tidak diterima. Walaupun kualitas layanan tidak mempengaruhi minat beli konsumen atas produk makanan/minuman di kabupaten Tangerang, ini bukan berarti kualitas layanan tidak penting, karena selain rasa enak dan nikmat yang di ingat oleh konsumen untuk datang kembali, kualitas layanan yang baik tidak bisa diabaikan. Maka dalam hal ini direkomendasikan bentuk pelatihan pengembangan usaha yang berfokus pada kualitas layanan jasa yang berorientasi pada pelanggan.

Harga memiliki pengaruh terhadap minat beli. Dari hasil signifikansi koefisien regresi $(0,037)$ dan nilai koefisien regresi $(0,292)$, harga mempengaruhi minat beli. Hipotesis ketiga diterima. Harga produk makanan/minuman yang ditawarkan pelaku UKM di Tangerang telah menimbulkan minat beli konsumen, terutama konsumen yang pengeluarannya perbulan Rp. 1.000.000,- sampai Rp.3,000,000,- Konsumen merasa harga produk makanan/minuman dapat di jangkau oleh mereka. Harga yang kompetitif selalu diingat oleh konsumen, membuat mereka datang kembali.

Saran untuk penelitian selanjutnya dapat menggunakan variabel lainnya, selain kualitas produk, layanan yang dirasakan, harga dan minat beli.

Keterbatasan yang terdapat dalam penelitian ini adalah sampel digunakan hanya di UPH Karawaci sehingga tidak dapat digeneralisasikan untuk keseluruhan konsumen produk makanan dan minuman UKM Tangerang.

\section{DAFTAR REFERENSI}

Albari \& Liriswati. 2004. Analisis Minat Beli Konsumen Sabun Cair Lux, Biore dan Lifebuoy di Kotamadya Yogyakarta Ditinjau dari Pengaruh Sikapnya Setelah Melihat Iklan di Televisi dan Norma Subyektif. Jurnal Siasat Bisnis, 2(9).

Budiyono \& Bernard, N.M. 2004. Studi Mengenai Pengembangan Strategi Produk. Jurnal Sains Pemasaran Indonesia, 3(2):181-194.

Dewa, N.K. 2009. Analisis Pengaruh Kualitas Produk Daya tarik Promosi dan Harga Terhadap Minat Beli Studi Kasus StarOne di Area Jakarta Pusat. Tesis Pascasarjana tidak dipublikasikan. Semarang: Universitas Diponegoro.

Ghozali, I. 2009. Aplikasi Analisis Multivariate Program SPSS. Semarang: Badan Penerbitan Universitas Diponegoro.

Keller \& Kevin L. 1987. Memory Factor in Advertising: The Effect of Advertising Retrieval Cues on Brand Evaluations. Journal of Customer Research, 14: 316-333.

Kotler, P. 2005. Marketing Management: Analysis, Planning, Implementation, and Control. Englewood Cliffs, NJ: PrenticeHall, Inc.

Sekaran, U \& Bougie, R. (2010). Research Methods for Business: A Skill Building Approach (5th edition). New Jersey: John Wiley and Sons.

Sheila \& Rahma. 2007. Analisis Pengaruh Kualitas Layanan dan Citra Merek Terhadap Minat Beli dan Dampaknya Pada Keputusan Studi Pada Pengguna Telepon Seluler Merek Sony Ericson di KotaSemarang. Tesis Pascasarjana tidak dipublikasikan. Semarang: Universitas Diponegoro.

Swastha, B. 1998. Manajemen Penjualan. Edisi Tiga. Yogyakarta: BPFE.

Tjiptono, F. 2009. Service Marketing Esensi dan Aplikasi. Malang: Bayu Media. 